\title{
STABILITAS SISTEM PERBANKAN DAN KEBIJAKAN MONETER: KETERKAITAN DAN PERKEMBANGANNYA DI INDONESIA
}

\author{
Perry Warjiyo ${ }^{1}$
}

\begin{abstract}
A b s tract
This paper reviews the inter-linkage between banking stability and monetary policy, with a reference to the Indonesian case since the 1997 crisis. In particular, it shows how monetary transmission mechanism would be inhibited and thus monetary policy would not be effective when the banking system is not sound and stable, such as during a crisis period. Conversely, the stance and response of monetary policy would have significant impacts on banking stability as inflation, exchange rate, and interest rate constitute major market risks to banking operations. For Indonesia, a close inter-linkage between banking instability and monetary policy ineffectiveness has been vividly evidenced during the crisis period of 1997-1999. Subsequently, however, with progress of the banking restructuring programs that Indonesian authorities have undertaken, the banking conditions have improved considerably since 2000. As banking intermediation improved, not only has financing to economic growth increased but also monetary transmission mechanisms strengthened considerably. Nonetheless, excess liquidity that banking system is still experiencing, especially because of lack of feasible investment outlets in the real sector and high perceived credit risks from the bankers, poses serious challenges to the central bank for better coordination and striking the optimal balance between maintaining monetary and banking stability while continue to promoting economic growth.
\end{abstract}

Keywords: Banking Stability, Monetary Policy, Indonesia.

JEL Classification: G21, E52, N25

1 Direktur Riset Ekonomi dan Kebijakan Moneter, Bank Indonesia, dan Dosen Fakultas Ekonomi, Universitas Indonesia. 


\section{PENDAHULUAN}

Stabilitas sistem perbankan dan stabilitas moneter merupakan dua aspek yang saling terkait dan menentukan satu sama lain. Stabilnya sistem perbankan secara umum dicerminkan dengan kondisi perbankan yang sehat dan berjalannya fungsi intermediasi perbankan dalam memobilisasi simpanan masyarakat untuk disalurkan dalam bentuk kredit dan pembiayaan lain kepada dunia usaha. Apabila kondisi seperti ini terpelihara, maka proses perputaran uang dan mekanisme transmisi kebijakan moneter dalam perekonomian yang sebagian besar berlangsung melalui sistem perbankan juga dapat berjalan baik. Dengan demikian, stabilnya sistem perbankan akan menentukan efektivitas pelaksanaan kebijakan moneter.

Demikian sebaliknya, terjaganya stabilitas moneter juga akan berpengaruh besar terhadap stabilitas sistem perbankan. Secara umum stabilitas moneter dicerminkan oleh terkendalinya inflasi, nilai tukar, suku bunga, dan besaran moneter seperti jumlah uang beredar dan kredit. Perkembangan inflasi, nilai tukar, dan suku bunga merupakan tiga elemen utama resiko pasar yang dihadapi perbankan. Dengan demikian, apabila perkembangan ketiga indikator ini berlangsung stabil, maka semakin kecil pula resiko pasar yang dihadapi perbankan sehingga akan mendukung terjaganya stabilitas sistem perbankan. Sebaliknya, dalam hal tekanan inflasi dan pelemahan nilai tukar meningkat sehingga memerlukan pengetatan moneter dengan kenaikan suku bunga yang tinggi, maka resiko pasar yang dihadapi perbankan juga akan semakin besar sehingga akan berpengaruh negatif terhadap stabilitas sistem perbankan.

Paper ini akan membahas keterkaitan antara perbankan dan kebijakan moneter dalam kerangka pemikiran hubungan stabilitas perbankan dan stabilitas moneter seperti di atas, dengan meletakkannya pada perkembangan dan permasalahan di Indonesia pasca krisis tahun 1997 hingga saat ini. Pembahasannya diramu ke dalam lima bagian. Setelah bagian pendahuluan, pada bagian kedua dibahas terlebih dahulu pemikiran konseptual dan teoritis mengenai keterkaitan tersebut dalam konteks fungsi dan peran perbankan dari perspektif mikro operasional perbankan maupun dari perspektif makro mekanisme transmisi kebijakan moneter dan intermediasi keuangan dalam ekonomi. Selanjutnya, bagian ketiga membahas keterkaitan stabilitas perbankan dan kebijakan moneter tersebut dalam konteks kondisi Indonesia pasca krisis tahun 1997, dengan menekankan pada beberapa permasalahan seperti penanganan krisis perbankan dan implikasinya bagi kebijakan moneter, fenomena credit crunch, peran perbankan dalam transmisi kebijakan moneter, hingga permasalahan disintermediasi keuangan. Bagian keempat menekankan pentingnya koordinasi kebijakan moneter dan kebijakan perbankan dengan mendasarkan pemikiran konseptual maupun kondisi Indonesia eratnya keterkaitan antara stabilitas perbankan dan stabilitas moneter di 
atas. Akhirnya, beberapa simpulan dan pelajaran penting dari keterkaitan stabilitas perbankan dan kebijakan moneter disampaikan pada bagian terakhir dari paper ini.

\section{FUNGSI DAN PERAN PERBANKAN: PERSPEKTIF MIKRO DAN MAKRO}

Apa yang khusus dari peran perbankan dalam ekonomi, baik dalam perspektif mikro operasional perbankan maupun perspektif makro sistem keuangan dan perekonomian, sehingga harus diatur dan diawasi secara ketat di berbagai negara? Dan, bagaimana peran khusus tersebut berimplikasi pada pentingnya koordinasi kebijakan moneter dengan kebijakan perbankan? Kedua pertanyaan mendasar ini penting untuk dibahas dan dipahami sebelum menganalisis keterkaitan antara stabilitas perbankan dan kebijakan moneter.

\section{II.1 Fungsi dan Peran Penting Perbankan}

Perbankan pada dasarnya merupakan lembaga perantara keuangan yang dalam operasinya menerima simpanan masyarakat dalam bentuk giro, tabungan dan deposito, yang kemudian menanamkan dana simpanan dimaksud dalam bentuk penyaluran kredit dan pembiayaan lain kepada dunia usaha maupun bentuk portfolio aset finansial seperti surat-surat berharga yang diterbitkan pemerintah dan bank sentral. Dalam perspektif ekonomi, karakteristik operasi perbankan seperti ini mempunyai kekhususan dalam fungsinya daripada lembaga keuangan lain, setidaknya dalam tiga aspek penting berikut ini (Guitan, 1997; George, 1997).

Pertama, dalam fungsinya sebagai lembaga kepercayaan untuk simpanan dana masyarakat, perbankan mempunyai fungsi khusus dalam penciptaan uang dan mekanisme sistem pembayaran dalam perekonomian. Simpanan masyarakat pada perbankan, bersamasama dengan uang kartal yang beredar dalam masyarakat, merupakan komponen uang beredar, baik dalam arti sempit (M1: uang kartal dan uang giral yaitu simpanan giro) maupun arti luas (M2: M1 dan uang kuasi yaitu tabungan deposito). Dengan keberadaan perbankan, berbagai transaski keuangan dan ekonomi yang semula dilakukan secara barter dan terbatas kemudian dapat berlangsung lebih cepat, aman, dan efisien. Kondisi ini juga didukung oleh mekanisme sistem pembayaran yang telah semakin berkembang, dari transaksi berbasis tunai pada ekonomi tradisional menjadi transaksi berbasis non-tunai (seperti transfer melalui kliring maupun penggunaan kartu elektronik) pada ekonomi modern. Terlebih lagi, dengan semakin berkembangnya sistem pembayaran dengan Real Time Gross Setlement (RTGS), proses penyelesaian pembayaran berbagai transaksi dalam ekonomi dapat semakin cepat, dilalukan secara serta merta, dan dalam jumlah yang besar (high value payments). 
Kedua, dalam fungsinya sebagai lembaga intermediasi keuangan, perbankan mempunyai fungsi khusus dalam memobilisasi simpanan masyarakat untuk disalurkan dalam bentuk kredit dan pembiayaan lain kepada dunia usaha. Dengan peran ini, perilaku menabung masyarakat dapat terdorong dan kebutuhan pembiayaan untuk berbagai kegiatan produksi dan investasi dalam ekonomi dapat terpenuhi. Demikian pula para debitur akan lebih mudah dalam memperoleh kredit atau pembiayaan untuk kebutuhan berbagai aktivitas produksi dan investasinya. Dengan demikian, mobilisasi dan alokasi sumber-sumber dana dalam ekonomi dapat semakin besar dan berlangsung lebih mudah dan efisien. Dalam konteks kebijakan moneter, fungsi intermediasi keuangan yang dilakukan perbankan seperti ini akan menentukan efektivitas transmisi kebijakan moneter yang ditempuh bank sentral dalam mempengaruhi berbagai kegiatan ekonomi dan keuangan sesuai dengan sasaran yang ingin dicapai, khususnya stabilitas harga dalam ekonomi. Perbankan mempunyai peran penting dalam transmisi kebijakan moneter, khususnya saluran uang, saluran kredit, dan saluran suku bunga karena proses perputaran uang berlangsung melalui perbankan.

Ketiga, dalam fungsinya sebagai lembaga penanaman aset finansial, perbankan mempunyai fungsi penting dalam pengembangan pasar keuangan, khususnya pasar uang domestik dan valuta asing. Dari karakteristik operasi yang dilakukan, perbankan berfungsi mentransformasi suatu aset finansial, yaitu simpanan masyarakat, ke dalam bentuk aset finansial lain, yaitu kredit dan penanaman dalam bentuk surat-surat berharga yang dikeluarkan pemerintah dan bank sentral. Transaksi keuangan yang dilakukan berlangsung baik dalam pasar uang rupiah maupun pasar valuta asing. Demikian pula, produk keuangan yang ditransaksikan terus berkembang, dari transaksi secara outright (tunai atau spot), repurchase agreement, spot atau forward, ataupun jenis-jenis transaksi yang lain. Meskipun tidak semua transaksi keuangan tersebut terkait langsung dengan transaksi ekonomi riil yang melandasinya, perputaran uang maupun hasil penanaman investasi akan mengalami peningkatan dan perluasan dari berbagai transaksi keuangan tersebut.

Ketiga fungsi penting seperti diuraikan di atas menempatkan perbankan pada peran khusus di dalam sistem ekonomi dan keuangan baik dari perspektif mikro maupun makro. Dari perspektif mikro, keberadaan perbankan diperlukan sebagai lembaga kepercayaan masyarakat untuk memenuhi kebutuhan dalam menyimpan dana, memperoleh kredit dan pembiayaan lain, maupun dalam melakukan berbagai transaksi ekonomi dan keuangan, dan karenanya keamanan dan kesehatan bank secara individual menjadi penting untuk dijaga dan dipelihara. Sementara dari perspektif makro, keberadaan dan stabilitas perbankan secara industri ataupun sistem diperlukan tidak saja karena pentingnya peran perbankan dalam proses penciptaan uang dan sistem pembayaran, tetapi juga dalam mendorong efektivitas mekanisme transmisi 
kebijakan moneter dan efisiensi alokasi sumber dana di dalam ekonomi. Dengan peran yang demikian penting baik dari perspektif mikro maupun makro tersebut, maka kesehatan dan stabilitas perbankan merupakan dua hal mendasar dan memerlukan suatu pengaturan dan pengawasan tertentu kepada perbankan. ${ }^{2}$

Pentingnya perbankan diatur dan diawasi dapat dilihat dari sifat operasi dan produk yang ditawarkannya yang semuanya menyangkut kepentingan publik, dan karenanya merupakan komoditas publik (public goods). Dari sisi simpanan yang diterima, misalnya, masyarakat mau menanamkan dananya di bank karena menaruh kepercayaan bahwa dana yang disimpannya akan tetap terjaga aman dan selalu tersedia sewaktu-waktu ditarik kembali dari bank untuk berbagai keperluan mereka. Bahkan tanpa adanya jaminan dari lembaga asuransi deposito dan atau pemerintah, masyarakat tetap saja percaya dan menyimpan dananya di perbankan. Permasalahan muncul apabila kepercayaan masyarakat menurun sehingga terjadi bank runs baik karena kondisi kesehatan suatu bank maupun efek domino suatu kegagalan bank kepada industri perbankan secara keseluruhan. Karena keberadaan perbankan sebagai suatu jasa pelayanan publik ditentukan oleh kepercayaan masyarakat seperti ini, maka peran otoritas dalam mengatur dan mengawasi operasi perbankan menjadi suatu keniscayaan untuk melindungi kepentingan publik tersebut.

Pentingnya perbankan diatur dan diawasi juga dilandasi oleh permasalahan agensi yang dihadapi masyarakat (sebagai prinsipal) yang menanamkan dananya pada perbankan (sebagai agen). Sebagai pihak yang menaruh kepercayaan atas dana yang disimpannya pada perbankan, masyarakat mempunyai kelemahan ataupun keterbatasan dalam mengawasi keamanan dana yang disimpannya. Ketersediaan informasi bank seperti kondisi keuangan maupun manajemen tidak secara mudah diperoleh maupun dipahami oleh masyarakat. Demikian pula, operasi maupun kondisi kesehatan perbankan dapat berubah secara cepat karena berbagai perkembangan baik internal maupun eksternal perbankan. Di sinilah perlunya peran bank sentral untuk mengatur dan mengawasi perbankan untuk mengatasi permasalahan agensi yang dihadapi masyarakat tersebut.

Dalam konteks yang lebih luas, pengaturan dan pengawasan perbankan semakin penting mempertimbangkan peran vital perbankan baik dalam intermediasi keuangan, sistem pembayaran, transmisi kebijakan moneter, maupun dalam alokasi sumber dana dalam perekonomian. Seperti diuraikan di atas, semakin sehat dan stabil perbankan maka akan semakin cepat dan besar perputaran uang dalam mendukung peningkatan kegiatan ekonomi riil. Tidak

2 Untuk uraian lebih rinci mengenai sistem dan kebijakan perbankan di Indonesia, baca Suseno dan Piter Abdullah (2003), Sistem dan Kebijakan Perbankan Indonesia, Buku Seri Kebanksentralan No. 6, Pusat Pendidikan dan Studi Kebanksentralan (PPSK), Bank Indonesia. 
dapat dibayangkan suatu perekonomian tanpa adanya perbankan. Krisis yang terjadi di Indonesia, khususnya pada tahun 1997-1999, menunjukkan bagaimana buruknya kondisi perbankan telah menyebabkan sulitnya ekonomi bergerak untuk pulih kembali.

\section{II.2 Perbankan dan Transmisi Kebijakan Moneter}

Seperti diuraikan di atas, salah satu kekhususan perbankan terkait erat dengan perannya dalam proses penciptaan uang di dalam perekonomian yang hampir seluruhnya berlangsung melalui sistem perbankan. Dengan peran seperti in, kondisi perbankan akan menentukan seberapa jauh efektivitas mekanisme transmisi kebijakan moneter yang ditempuh bank sentral dapat berpengaruh terhadap berbagai aktivitas ekonomi dan keuangan. Dalam kaitan ini, mekanisme transmisi moneter dimulai dari tindakan bank sentral dengan menggunakan instrumen moneter, apakah Operasi Pasar Terbuka (OPT) atau yang lain, dalam melaksanakan kebijakan moneternya untuk mencapai sasaran akhir yang diinginkan, yaitu inflasi dan pertumbuhan ekonomi. Tindakan itu kemudian berpengaruh terhadap aktivitas ekonomi dan keuangan melalui berbagai saluran transmisi kebijakan moneter, yaitu saluran uang, kredit, dan suku bunga untuk yang pada umumnya berlangsung melalui sistem perbankan. ${ }^{3}$

Keterkaitan kebijakan moneter dengan perbankan tersebut terjadi melalui dua tahap transmisi moneter dalam proses perputaran uang. Pertama, interaksi antara bank sentral dengan perbankan dalam berbagai transaksi di pasar uang yang berkaitan dengan operasi moneter bank sentral dan manajemen likuiditas oleh perbankan. Dengan interaksi ini, kebijakan moneter berpengaruh terhadap perkembangan suku bunga, volume dana masyarakat yang disimpan di bank, kredit yang disalurkan bank kepada dunia usaha, dan perkembangan transaksi pasar uang yang dilakukan oleh perbankan. ${ }^{4}$ Kedua, interaksi antara perbankan dengan para pelaku ekonomi di sektor riil dalam proses intermediasi keuangan dalam berbagai aktivitas ekonomi baik dalam bentuk penerimaan simpanan dari masyarakat maupun penyaluran kredit kepada dunia usaha. Perkembangan ini akan menentukan pengaruh kebijakan moneter terhadap perkembangan permintaan agregat di sektor riil, baik konsumsi maupun investasi, dan pada

3 Selain tiga saluran tersebut, mekanisme juga berlangsung melalui saluran nilai tukar, harga aset, dan ekspektasi. Untuk uraian lebih rinci mengenai mekanimse transmisi kebijakan moneter, baca Perry Warjiyo (2004), Mekanisme Transmisi Kebijakan Moneter, Seri Kebanksentralan No. 11, Pusat Pendidikan dan Studi Kebanksentralan (PPSK), Bank Indonesia. Untuk studi menyeluruh mengenai berbagai saluran transmisi kebijakan moneter, baca Perry Warjiyo dan Juda Agung (2002), Monetary Policy Transmission Mechanisms in Indonesia, Bank Indonesia.

4 Pengaruh interaksi antara bank sentral dengan perbankan akan tergantung pada operasi moneter yang dilakukan bank sentral dalam OPT, yaitu apakah berdasar pendekatan kuantitas (uang primer) atau pendekatan harga (suku bunga jangka pendek) sebagai sasaran operasional. Interaksi berdasar sasaran operasional uang primer seperti yang dijelaskan dalam saluran uang di atas, sementara interaksi berdasar sasaran operasional suku bunga bekerja seperti pada transmisi saluran suku bunga yang dijelaskan dalam subbagian selanjutnya. 
akhirnya akan menentukan tingkat pertumbuhan ekonomi dan inflasi yang merupakan sasaran akhir kebijakan moneter.

Dalam kondisi normal, ketika tidak ada gangguan signifikan atas kelangsungan intermediasi perbankan maupun perkembangan pasar uang dan pasar kredit, ketiga saluran transmisi moneter yang menunjukkan keterkaitan antara operasi perbankan dan operasi moneter tidak menunjukkan perbedaan berarti. Dalam kondisi demikian, perbankan mampu memobilisasi simpanan masyarakat dan menciptakan uang beredar secara baik sebagai bentuk dari bekerjanya saluran transmisi uang beredar. Dana masyarakat tersebut juga dapat secara normal disalurkan dalam bentuk kredit kepada debitur, tanpa adanya gangguan baik dari sisi internal perbankan maupun kondisi keuangan debitur, sehingga mekanisme transmisi melalui saluran kredit perbankan juga berlangsung normal. Demikian pula, tidak adanya gangguan dalam struktur dan operasi pasar uang dan pasar kredit mampu mendorong bekerjanya pengaruh perubahan suku bunga kebijakan moneter terhadap suku bunga deposito dan kredit perbankan secara normal dengan tenggat waktu (lag) yang juga pendek.

Akan tetapi, kondisi faktual tidak selalu mengarah pada keseimbangan baik pada pasar uang maupun pasar kredit secara segera dan penuh. Dalam konteks operasi perbankan, saluran transmisi moneter melalui kredit perbankan menjadi penting terutama kelemahan asumsi saluran uang bahwa semua dana yang dimobilisasi perbankan dari masyarakat dalam bentuk uang beredar (M1, M2) dipergunakan untuk pendanaan aktivitas sektor riil melalui penyaluran kredit perbankan. Dalam kenyataannya, asumsi seperti tidak selamanya benar. Selain dana yg tersedia, perilaku penawaran kredit perbankan juga dipengaruhi oleh persepsi bank terhadap prospek usaha debitur dan kondisi perbankan itu sendiri seperti pemodalan (CAR), jumlah kredit macet (NPL), dan Loan to Deposit Ratio (LDR). Selain itu, tidak semua permintaan kredit debitur dapat dipenuhi oleh bank-bank, khususnya karena kondisi keuangan debitur yang dinilai oleh bank tidak memenuhi persyaratan antara lain karena tingginya rasio utang terhadap modal (leverage), resiko kredit macet, moral hazard, dan sebagainya. Adanya informasi yang tidak simetris (assymetric information) antara bank dengan debitur seperti itu dapat menyebabkan pasar kredit tidak selalu berada dalam keseimbangan. ${ }^{5}$

Dengan alasan serupa, dalam hal ketidakseimbangan pasar uang dan pasar kredit terjadi, baik karena kondisi perbankan maupun struktur dan operasi pasar keuangan, bekerjanya saluran uang beredar belum dapat menjamin bahwa saluran suku bunga juga berjalan normal. Berbeda

5 Pemikiran seperti ini yang juga melandasi kritik tajam dari Stiglitz dan Greenwald (2003) terhadap pelaksanaan kebijakan moneter berdasar tranmisi uang. Ekonom ternama ini menekankan pentingnya aspek kelembagaan dan ketidakseimbangan dalam pasar kredit dalam memahami teori dan kebijakan moneter. Untuk jelasnya, baca Joseph E. Stigliz dan Bruce Greenwald, Towards a New Paradigm in Monetary Economics, Cambridge University Press, 2003. 
dengan saluran uang dan saluran kredit yang mementingkan aspek kuantitas dari proses perputaran uang dalam ekonomi, saluran suku bunga (interest rate channel) lebih menekankan pentingnya aspek harga di pasar keuangan terhadap berbagai aktivitas ekonomi di sektor riil. Dengan demikian, kebijakan moneter yang ditempuh bank sentral akan berpengaruh terhadap perkembangan berbagai suku bunga di sektor keuangan, selanjutnya pada perkembangan konsumsi dan investasi, dan akhirnya pada tingkat inflasi dan output riil. Proses transmisi suku bunga tersebut biasanya tidak selalu berlangsung secara segera, atau terdapat tenggat waktu, terutama karena kondisi internal perbankan dalam manajemen aset and kewajibannya (ALMAAsset and Liability Management).

Uraian di atas menunjukkan bahwa kondisi perbankan berpengaruh besar terhadap bekerjanya dan efektivitas saluran transmisi moneter khususnya saluran uang, saluran kredit, dan saluran suku bunga. Dalam kondisi dimana kesehatan dan stabilitas perbankan terjaga dan berkembang kuat, ketiga saluran transmisi ini tidak menunjukkan perbedaan yang berarti. Akan tetapi, dalam kondisi ketika perbankan sedang mengalami sejumlah permasalahan sehingga proses intermediasi keuangan maupun pasar keuangan tidak berjalan normal, maka perilaku ketiga saluran transmisi moneter tersebut akan menunjukkan perbedaan.

\section{II.3 Keterkaitan Stabilitas Perbankan dan Kebijakan Moneter}

Uraian mengenai peran perbankan seperti di atas menunjukkan eratnya keterkaitan dan pentingnya koordinasi kebijakan perbankan (perspektif mikro) dan kebijakan moneter (perspektif makro). Seperti diuraikan di atas, perbankan yang aman, sehat, dan stabil merupakan sasaran kebijakan perbankan yang pada dasarnya dilakukan melalui instrumen-instrumen perizinan, pengaturan kehati-hatian, pengawasan langsung maupun tidak langsung, serta penanganan bank-bank yang mengalami kesulitan. Sementara dalam konteks kebijakan moneter, sasaran akhir yang diutamakan adalah kestabilan harga (inflasi), dan atau kestabilan nilai tukar (kurs) pada sejumlah negara, yang akan dicapai melalui operasi moneter yang pada umumnya melalui pengendalian suku bunga di pasar uang. ${ }^{6}$ Dengan peran perbankan dalam proses penciptaan uang dan transmisi kebijakan moneter seperti diuraikan di atas, pelaksanaan kebijakan moneter jelas tidak dapat berjalan efektif tanpa adanya kondisi perbankan yang sehat dan stabil. Demikian pula, perubahan suku bunga, nilai tukar, dan inflasi akibat pelaksanaan kebijakan moneter jelas akan berpengaruh pada kesetahatan dan kestabilan perbankan melalui perubahan resiko pasar yang terkandung pada kondisi keuangan dan permodalan perbankan.

6 Untuk uraian lebih rinci mengenai sistem dan kebijakan perbankan di Indonesia, baca Perry Warjiyo dan Solikin (2003), Kebijakan Moneter di Indonesia, Buku Seri Kebanksentralan No. 5, Pusat Pendidikan dan Studi Kebanksentralan (PPSK), Bank Indonesia. 
Pencapaian sasaran kestabilan moneter dapat didukung oleh pencapaian kesehatan dan kestabilan perbankan melalui beberapa aspek (Guitan, 1997). Sistem perbankan yang sehat diperlukan agar sinyal kebijakan moneter dapat ditransmisikan secara efektif ke berbagai aktivitas ekonomi. Apabila kondisi bank-bank rentan, bank sentral jelas akan mengalami kesulitan untuk menilai keterkaitan instrumen kebijakan moneter yang ditempuhnya dengan arah kinerja perekonomian yang diinginkan sehingga akan mempersulit perumusan kebijakan moneter yang akan ditempuh. Dengan kondisi perbankan yang memburuk, efektivitas kebijakan moneter juga akan terhambat karena bank-bank tidak akan dan mampu merespon sinyal kebijakan moneter secara baik. Lebih dari itu, distorsi dalam mekanisme transmisi kebijakan moneter akan semakin besar dalam hal terjadi perilaku moral hazard maupun adverse selection risks yang muncul diantara para pelaku perbankan. Alokasi kredit dapat tidak efisien dan dapat menimbulkan dampak negatif terhadap aktivitas ekonomi riil secara keseluruhan. Dengan kata lain, fenomena credit crunch dan disintermediasi perbankan jelas akan berpengaruh besar terhadap efektivitas transmisi kebijakan moneter dan pencapaian sasaran stabilitas moneter yang dikehendaki oleh bank sentral.

Kendala juga dapat dihadapi oleh bank sentral dalam melaksanakan kebijakan moneter dalam hal terjadi ketidaksehatan bank secara individual sehingga memerlukan pemberian lender of last resort (LOLR) oleh bank sentral. Bahkan dalam konteks terjadi kesulitan perbankan secara sistemik atau industri secara keseluruhan sehingga kelangsungan perekonomian terancam, pemberian financial system safety net (FSN) melalui pembebanan anggaran fiskal oleh Pemerintah dengan atau tanpa pembiayaan dari bank sentral sering diperlukan. Dalam kondisi demikian, pemberian LOLR atau FSN akan mengubah neraca bank sentral dan karenanya akan mempengaruhi uang beredar dan suku bunga yang juga perlu dikendalikan dalam menjaga stabilitas moneter, khususnya pencapaian sasaran inflasi dan kestabilan nilai tukar, yang diperlukan untuk mendorong pertumbuhan ekonomi. Dalam hal operasi moneter dilakukan berdasar kaidah baku tertentu seperti untuk mencapai target pertumbuhan uang beredar dalam jumlah tertentu, pemberian LOLR dan FSN tersebut dapat dibatasi atau bahkan dilarang sama sekali. Akan tetapi, apabila rezim kebijakan moneter yang dianut lebih akomodatif, bank sentral dapat terdorong untuk memberikan LOLR dan FSN dalam jumlah yang lebih besar. Dalam kondisi demikian, meskipun sasaran kesehatan bank dan kestabilan sistem perbankan mungkin dapat dicapai, akan tetapi jumlah uang beredar dapat meningkat pesat sehingga sasaran kestabilan harga (dan nilai tukar) dapat terkendala.

Dengan pemikiran demikian, kebijakan moneter dan kebijakan perbankan (dan sistem keuangan) merupakan dua aspek yang saling terkait dan menentukan (Sinclair, 2001). Dari sisi kebijakan moneter, perubahan suku bunga, nilai tukar, dan inflasi akibat pelaksanaan kebijakan moneter jelas akan berpengaruh pada kesetahatan dan kestabilan perbankan melalui perubahan 
resiko pasar yang terkandung pada kondisi keuangan dan permodalan perbankan. Apabila inflasi dan nilai tukar terus mengalami peningkatan dan berfluktuasi, misalnya, maka akan terjadi proses redistribusi aset riil dari masyarakat penyimpan dana (investor) kepada para debitur kredit perbankan, khususnya dengan suku bunga tetap. Simpanan masyarakat dapat saja turun, sementara resiko kredit debitur dapat meningkat dengan menurunnnya permintaan riil atas produk usaha debitur. Dengan kata lain, volatilitas inflasi dan nilai tukar akan meningkatkan resiko perbankan, khususnya resiko likuditas dari sisi simpanan dana masyarakat dan resiko kredit macet dari sisi kondisi usaha debitur.

Demikian pula, operasi moneter juga berdampak pada perbankan dalam hal terjadi perubahan suku bunga yang diperlukan untuk pengendalian inflasi dan nilai tukar. Peningkatan dan volatilitas inflasi dan nilai tukar jelas akan meningkatkan resiko pasar yang terkandung dalam neraca bank-bank. Selain itu, perubahan suku bunga yang relatif besar dalam jangka pendek jelas akan meningkatkan ketidakpastian dalam pasar keuangan dan resiko pasar yang dihadapi perbankan. Apalagi apabila terjadi penundaan suku bunga, sehingga pada waktu suku bunga benar-benar diubah diperlukan perubahan yang relatif besar, dampak terhadap resiko yang dihadapi perbankan semakin besar. Dengan kata lain, perubahan kebijakan moneter secara gradual dan dilakukan pada waktu yang tepat dan dapat diantisipasi akan berdampak relatif lebih kecil pada resiko perbankan.

Sebaliknya, kebijakan yang ditempuh bank sentral untuk menjaga kesehatan dan stabilitas sistem perbankan juga dapat berdampak pada kondisi dan pelaksanaan kebijakan moneter. Pengawasan terhadap perbankan yang lebih efektif dan ketat, misalnya, akan meningkatkan kesehatan dan mengurangi resiko insolvensi perbankan. Kondisi ini akan meningkatkan kepercayaan masyarakat, dan karenanya akan meningkatkan dana yang disimpan pada perbankan. Apabila kondisi ini dibarengi dengan pengendalian uang beredar yang optimal dari sisi kebijakan moneter, maka tekanan terhadap inflasi juga akan lebih mudah dikendalikan.

Akan tetapi, semakin ketatnya pengawasan perbankan akan cenderung mendorong bankbank lebih ekstra hati-hati dalam menyalurkan kredit dan menyediakan pembiayaan lain yang diperlukan sektor riil. Disintermediasi finansial bisa saja terjadi, dalam arti peningkatan simpanan dana dari masyarakat tidak diikuti dengan peningkatan penyaluran kredit dan pembiayaan lain kepada dunia usaha. Apabila kondisi ini diikuti pula dengan moral hazard dan adverse selection bias, dalam arti penyaluran kredit lebih banyak diberikan kepada debitur yang berani membayar suku bunga yang tinggi, atau bahkan terjadi fenomena credit crunch seperti diuraikan di atas, maka resiko kredit macet perbankan juga akan meningkat. Perkembangan seperti ini tidak saja akan membuat rentan kondisi kesehatan dan kestabilan perbankan, tetapi juga kurang efektifnya kebijakan moneter dan aktivitas ekonomi riil secara keseluruhan. 
Dari uraian di atas, keterkaitan yang erat antara kesehatan dan kestabilan perbankan dengan kebijakan moneter menekankan pentingnya koordinasi antara kebijakan moneter dan kebijakan perbankan. Secara lebih rinci, keterkaitan ini dapat diletakkan pada empat aspek. Pertama, perbankan mempunyai peran penting dan menentukan dalam mekanisme transmisi kebijakan moneter dalam mencapai sasaran akhir yang diinginkan, yaitu inflasi dan atau stabilitas nilai tukar. Kedua, perbankan menghadapi resiko pasar dari pelaksanaan kebijakan moneter, khususnya dalam bentuk perubahan suku bunga, nilai tukar, dan inflasi. Ketiga, sejumlah instrumen kebijakan mempunyai dua aspek pengaruh baik pada perbankan ataupun moneter, seperti reserve requirement, discount facility, maupun net open position. Keempat, penanganan kesulitan perbankan, seperti dengan lenders of last resort ataupun financial sistem safety net, akan mempunyai implikasi penting pada pelaksanaan kebijakan moneter.

\section{PERKEMBANGAN DAN PERMASALAHAN DI INDONESIA}

Kondisi Indonesia pasca krisis tahun 1997 hingga dewasa ini menunjukkan bagaimana eratnya keterkaitan stabilitas perbankan (dan sistem keuangan) dengan kebijakan moneter. Pada tahap awal krisis tahun 1997-1998, misalnya, industri perbankan Indonesia mengalami berbagai permasalahan struktural sebagai akibat dari krisis nilai tukar (moneter) maupun kondisi internal perbankan sendiri. Berbagai kebijakan yang ditempuh Pemerintah dan Bank Indonesia juga tidak mudah dan sering dilematis karena berat dan kompleksitas keterkaitan krisis perbankan dan krisis moneter tersebut. Fenomena credit crunch kemudian terjadi sebagai fenomena disintermediasi keuangan dalam perbankan Indonesia yang menyebabkan efektivitas transmisi kebijakan moneter terkendala. Perbaikan kinerja perbankan secara signifkan mulai terjadi sejak tahun 2000 dengan ditempuhnya serangkaian kebijakan restrukturisasi perbankan dan didukung oleh kebijakan moneter akomodatif Bank Indonesia, meskipun kemudian terpengaruh dengan adanya pengetatan moneter pada tahun 2005 .

\section{III.1 Krisis Perbankan dan Kebijakan Moneter}

Telah begitu banyak paper atau buku yang membahas bagaimana krisis perbankan di Indonesia terjadi, dampaknya terhadap kondisi perbankan, serta langkah-langkah kebijakan yang telah ditempuh Pemerintah dan Bank Indonesia.? Pada dasarnya krisis nilai tukar yang terjadi dalam kondisi internal perbankan yang rentan telah menyebabkan berat dan kompleksnya

\footnotetext{
7 Lihat, misalnya, Enoch et. al. (2001) untuk studi menyeluruh mengenai evolusi sebab, dampak, dan langkah-langkah kebijakan yang
} ditempuh Pemerintah dalam penanganan krisis perbankan di Indonesia. 
berbagai permasalahan krisis perbankan di Indonesia. Di sisi pasiva, merosotnya nilai tukar rupiah telah menyebabkan membengkaknya kewajiban luar negeri perbankan Indonesia, khususnya yang mempunyai eksposur utang luar negeri. Rendahnya kepercayaan masyarakat atas perbankan, baik karena terjadinya krisis maupun adanya ketidakkonsistenan penutupan bankbank pada Oktober 1997 dan Mei 1998, telah menyebabkan penarikan dana secara besarbesaran (bank runs) dan kesulitan likuiditas yang parah pada perbankan. Sementara di sisi aktiva, kesulitan perbankan diperparah dengan melonjaknya kredit bermasalah (non-performing loans$\mathrm{NPL}$ ) karena semakin banyaknya debitur yang bangkrut karena krisis ekonomi yang terjadi. Pada akhirnya berbagai permasalahan tersebut telah menyebabkan bank-bank yang mengalami kerugian besar dan kemudian insolven, bahkan banyak bank yang modalnya negatif.

Untuk mengatasi krisis perbankan, Pemerintah telah menempuh kebijakan restrukturisasi menyeluruh terhadap industri perbankan Indonesia. Untuk mengatasi bank runs akibat merosotnya kepercayaan masyarakat, Pemerintah menempuh Program Penjaminan atas seluruh kewajiban bank-bank baik kepada para deposan maupun pihak lain, termasuk kewajiban dalam bentuk utang luar negeri dan pembayaran letter of credit yang dikeluarkan oleh perbankan Indonesia. Program rekapitalisasi juga ditempuh untuk mengatasi permasalahan permodalan perbankan dengan penerbitan obligasi atau Surat Utang Negara (SUN) untuk penyertaan tambahan modal oleh Pemerintah. Selain itu, untuk mengatasi kredit bermasalahan, program restukturisasi kredit juga ditempuh baik melalui BPPN maupun Satuan Tugas Restrukturisasi Kredit di bank-bank.

Berbagai langkah kebijakan yang ditempuh Pemerintah tersebut secara berangsur-angsur telah mendorong proses pemulihan perbankan. Kepercayaan masyarakat terhadap perbankan telah pulih sehingga masyarakat tidak lagi merasa takut menyimpan dana pada perbankan dan bahkan dana perbankan terus mengalami peningkatan. Kepercayaan pihak luar negeri juga telah pulih, dengan telah berjalan normalnya berbagai aktivitas luar negeri perbankan Indonesia baik dalam transaksi keuangan maupun dalam mendukung aktivitas perdagangan internasional. Permasalahan permodalan perbankan juga dapat diatasi dengan adanya tambahan modal atau rekapitalisasi oleh Pemerintah sehingga perbankan dapat kembali beroperasi secara normal. Demikian pula, kredit dan pembiayaan lain yang disalurkan perbankan untuk membiayai berbagai aktivitas ekonomi masyarakat, khususnya untuk modal kerja dan konsumsi, juga telah mengalami peningkatan.

Namun di sisi lain, berbagai langkah kebijakan tersebut juga telah menimbulkan sejumlah permasalahan, baik dalam konteks penyehatan perbankan maupun dalam kaitannya dengan pelaksanaan kebijakan moneter, khususnya pada periode awal krisis hingga tahun 1999. Sebagai contoh, pelaksanaan Program Penjaminan Pemerintah telah dilaksanakan dengan dana talangan dari Bank Indonesia, yang kemudian dikenal dengan Bantuan Likuiditas Bank Indonesia (BLBI). 
Besarnya dana BLBI yang harus disediakan Bank Indonesia untuk mengatasi rush terhadap perbankan, khususnya pada tahun 1997 dan 1998, telah menyebabkan ekspansi jumlah uang beredar dalam jumlah yang sangat besar di dalam ekonomi. Untuk mengurangi dampak ekspansi moneter tersebut terhadap inflasi dan merosotnya nilai tukar lebih lanjut, Bank Indonesia terpaksa harus melakukan pengetatan moneter sehingga suku bunga SBI mengalami peningkatan hingga mencapai tertinggi sebesar $68,76 \%$ pada September 1998. Langkah pengetatan moneter ini secara berangsur-angsur mampu menurunkan tekanan inflasi dan nilai tukar, seperti tercermin pada turunnya inflasi dari 77,54\% pada tahun 1998 menjadi 2,01\% pada tahun 1999.

Demikian pula, obligasi rekapitalisasi yang dikeluarkan Pemerintah juga menimbulkan permasalahan kurang produktifnya aset yang dimiliki perbankan untuk peningkatan intermediasi keuangan bagi ekonomi pada periode awal krisis hingga tahun 1999. Dengan masih tingginya risiko kredit dan berbagai permasalahan di sektor riil, obligasi tersebut lebih banyak berada dalam portfolio aset perbankan dari pada disalurkan dalam bentuk kredit untuk dunia usaha. Akibatnya, fungsi intermediasi perbankan dan transmisi kebijakan moneter menjadi terkendala. Dengan mulai diperdagangkan obligasi rekapitalisasi tersebut di pasar sekunder sejak tahun 2002 dengan langkah-langkah penataan perdagangan obligasi Pemerintah di pasar sekunder oleh Bank Indonesia, sejak tiga tahun terakhir perdagangan obligasi rekapitalisasi di pasar sekunder telah mengalami peningkatan dalam jumlah yang besar. Fungsi intermedias perbankan juga berangsur-angsur pulih sehingga meningkatkan pula efektivitas transmisi kebijakan moneter.

Uraian di atas menunjukkan bagaimana eratnya keterkaitan langkah-langkah restrukturisasi untuk memulihkan kesehatan dan stabilitas perbankan dengan kebijakan moneter. Perkembangan yang terjadi, khususnya pada periode tahun 1997-1999, menunjukkan bagaimana langkah-langkah penyehatan perbankan dengan penyediaan dana dari bank sentral telah menjadi dilema karena keharusan bank sentral untuk melakukan pengetatan moneter untuk meminimalkan dampak ekspansi moneter dari pendanaan bank sentral untuk penyehatan perbankan tersebut pada kenaikan inflasi yang lebih tinggi dan gejolak nilai tukar yang lebih besar lagi. Demikian pula, rekapitalisasi perbankan dengan penerbitan obligasi pemerintah telah menyebabkan terkendalanya intermediasi perbankan dan efektvitas transmisi kebijakan moneter di dalam ekonomi.

\section{III.2 Credit Crunch: Pengaruh Kondisi Perbankan, Debitur, atau Kebijakan Moneter?}

Seperti dikemukakan di atas, fenomena credit crunch terjadi dalam perbankan Indonesia dengan terkendalanya penyaluran kredit, khususnya pada periode awal terjadinya krisis. Secara 
umum credit crunch merupakan fenomena terjadinya ketidakseimbangan di pasar kredit yang dapat disebabkan oleh faktor-faktor di sisi penawaran kredit oleh perbankan, sisi permintaan dari debitur, ataupun kondisi ekonomi dan moneter yang berpengaruh terhadap penyaluran kredit perbankan, khususnya kebijakan moneter. Kondisi internal yang umumnya berpengaruh besar terhadap perilaku perbankan dalam penawaran kredit adalah suku bunga kredit, suku bunga atau yield alternatif penanaman dana di luar kredit, kemampuan permodalan bank, besarnya kredit bermasalah (NPL) sebagai cerminan dari resiko kredit, maupun kapasitas pemberian pinjaman atau kondisi LDR bank yang bersangkutan. Kondisi internal debitur yang umumnya berpengaruh besar terhadap perilaku debitur dalam permintaan kredit adalah prospek bisnis atau tingkat kelayakan proyek atau aktivitas ekonomi yang akan dibiayai (cash flow), suku bunga kredit perbankan relatif terhadap biaya modal untuk alternatif pembiayaan seperti emisi saham dan obligasi, tingkat leverage (debt-equity ratio) maupun kemampuan manajerial debitur. Sementara itu, kebijakan moneter berdampak pada pasar kredit melalui pengaruhnya terhadap pembentukan ekspektasi perbankan maupun debitur atas arah pergerakan variabel-variabel seperti pertumbuhan ekonomi, inflasi, nilai tukar, dan suku bunga dalam menyusun dan menganalisis tingkat kelayakan proyek yang akan dibiayai kredit tersebut.

Secara makro, credit crunch dapat menghampat pertumbuhan ekonomi mengingat sumber pembiayaan dunia usaha sangat tergantung pada kredit perbankan. Credit crunch yang terus berlangsung dapat memberikan second round effect pada kegagalan bisnis dunia usaha, yang pada akhirnya kembali memperburuk kualitas pinjaman perbankan dan resiko terjadinya kembali krisis keuangan. Bagi kepentingan pengendalian moneter, credit crunch memiliki implikasi terhadap efektivitas pengendalian moneter karena respon perbankan dalam mentransmisikan pengaruh sinyal kebijakan moneter terhadap berbagai aktivitas keuangan dan ekonomi tidak dapat berjalan seperti yang diharapkan bank sentral.

Untuk kasus Indonesia, Agung et. al. (2001) melakukan penelitian untuk mengkaji faktor-faktor yang menyebabkan lambatnya penyaluran kredit setelah terjadi krisis pada periode Agustus 1997-Desember 1999 dengan pembandingan periode sebelum krisis dari Januari 1994Juli 1997. Secara khusus, penelitian ini melihat apakah menurunnya kredit berasal dari faktor penawaran akibat keengganan bank untuk menyalurkan kredit dan bank yang menjadi lebih berhati-hati (risk averse) seperti dihipotesakan oleh fenomena credit crunch, atau memang karena rendahnya permintaan kredit akibat perekonomian yang kurang kondusif dan konsolidasi internal perusahaan (balance sheet adjustments). Studi empiris dilakukan baik secara makro dengan menggunakan data agregat maupun secara mikro dengan menggunakan data individual perbankan, Disamping pemodelan kuantitatif, analisis kualitatif juga dilakukan berdasarkan 
hasil survei kepada perbankan untuk mengkaji sisi penawaran kredit maupun kepada perusahaan untuk sisi permintaan kredit.

Secara keseluruhan hasil studi menunjukkan bahwa masih lambannya penyaluran kredit oleh perbankan pada periode 1997-1999 lebih disebabkan oleh faktor-faktor penawaran seperti dihipotesakan oleh fenomena credit crunch. Hal ini terutama akibat persoalan permodalan yang dialami oleh bank setelah terjadinya krisis (capital crunch), meningkatnya NPLs, tingginya resiko kredit di dunia usaha sebagaimana yang tercermin dari masih tingginya tingkat leverage, dan kurangnya informasi mengenai debitur yang potensial.

Dalam penelitan selanjutnya, Agung et. al. (2002) menunjukkan bahwa kebijakan moneter berpengaruh terhadap kredit perbankan dengan tenggat waktu karena kemampuan bank dalam menghindari penurunan volume deposito dengan menjual surat-surat berharga yang dimilikinya. Ini dilakukan bank untuk memenuhi komitmen kredit yang telah diberikan sebelum terjadi perubahan kebijakan moneter. Bukti empiris juga menunjukkan bahwa setelah perubahan kebijakan moneter terdapat "flight to quality" atas deposito dari bank nasional ke bank asing dan campuran. Dari sisi kelompok bank menurut besarnya modal, studi ini menunjukkan bahwa pengaruh kebijakan moneter lebih kuat pada bank-bank yang modalnya relatif kecil. Lebih jauh lagi, analisis data time series dan panel data dalam studi ini menunjukkan bahwa pengaruh kebijakan moneter terhadap kredit perbankan berperilaku asimetris yaitu cenderung lebih kuat dalam kondisi resesi dibandingkan dalam periode booming.

Fenomena credit crunch seperti di atas mempunyai implikasi yang sangat penting bagi kebijakan moneter. Pertama, efektivitas kebijakan moneter menjadi terkendala karena tidak berjalannya mekanisme transmisi kebijakan moneter melalui perbankan. Hal ini terutama disebabkan karena penyaluran kredit perbankan tidak banyak ditentukan oleh pergerakan suku bunga akan tetapi lebih didorong oleh faktor-faktor seperti adverse selection dan resiko dunia usaha. Kedua, dalam kondisi lemahnya keuangan perusahaan, pengaruh kebijakan moneter dapat bersifat asimetris. Dalam hal ini, ekspansi moneter berupa turunnya suku bunga tidak serta merta akan meningkatkan penyaluran kredit perbankan dan investasi dunia usaha. Akan tetapi sebaliknya, kontraksi moneter berupa kenaikan suku bunga akan semakin memperburuk kondisi keuangan perusahaan, dan karenanya semakin membatasi lebih lanjut penyaluran kredit oleh perbankan.

\section{III.3 Transmisi Moneter melalui Saluran Kredit}

Sejumlah studi dapat memberikan gambaran mengenai bagaimana kondisi Indonesia sebelum dan sesudah krisis tahun 1997 berdampak pada bekerjanya transmisi kebijakan moneter. 
Studi yang dilakukan Agung et. al. (2002) merupakan kelanjutan dari studi mengenai saluran kredit yang dilakukan sebelumnya (Agung, 1998; Agung, 2000; Agung et. al., 2001). Secara keseluruhan studi ini memberikan bukti empiris yang lengkap mengenai bekerjanya saluran kredit perbankan (banks lending channel) dalam transmisi moneter di Indonesia sebelum dan sesudah krisis. Mempertimbangkan kenyataan adanya ketergantungan debitur terhadap kredit perbankan, studi ini lebih memfokuskan pada pertanyaan apakah kebijakan moneter berpengaruh besar terhadap volume kredit bank.

Bukti dari analisis data agregat menunjukkan bahwa kebijakan moneter berpengaruh terhadap kredit perbankan dengan tenggat waktu karena kemampuan bank dalam menghindari penurunan volume deposito dengan menjual surat-surat berharga yang dimilikinya. Ini dilakukan bank untuk memenuhi komitmen kredit yang telah dilakukannya sebelum terjadi perubahan kebijakan moneter tersebut. Bukti empiris lebih jauh menunjukkan bahwa setelah perubahan kebijakan moneter terdapat "flight to quality" atas deposito dari bank nasional ke bank asing dan campuran. Kondisi ini dapat menerangkan mengapa kredit dari bank asing dan campuran tidak terlalu sensitif terhadap perubahan kebijakan moneter dibanding bank swasta nasional.

Disagregasi data kredit perbankan ke dalam kredit individual dan korporasi menunjukkan bahwa kredit korporasi relatif kurang sensistif terhadap pengaruh kebijakan moneter, sementara kredit individual mengalami penurunan yang tajam. Hal ini dapat dijelaskan dengan fenomena "flight to quality" atas pemilihan debitur oleh perbankan dalam hal terjadi pengetatan moneter, yaitu hanya perusahaan yang benar-benar feasibel saja yang mendapatkan kredit jangka pendek sementara perusahaan yang kurang feasibel dan individual akan menghadapi penjatahan kredit. Dari sisi kelompok bank menurut besarnya modal, bukti empiris dari studi ini menunjukkan bahwa pengaruh kebijakan moneter lebih kuat pada bankbank yang modalnya relatif kecil.

Lebih jauh lagi, analisis data time series dan panel data dalam studi ini menunjukkan bahwa pengaruh kebijakan moneter terhadap kredit perbankan dan investasi perusahaan lebih kuat pada periode setelah krisis, khususnya dalam hal terjadi pengetatan moneter. Kurang efektifnya kebijakan moneter dalam mempengaruhi kredit perbankan pada periode sebelum krisis terutama disebabkan oleh kemampuan bank-bank dalam mengakses dana luar negeri. Setelah terjadinya krisis, dengan menurunnya permodalan bank dan tingginya risiko kredit, kenaikan suku bunga yang timbul dari kontraksi moneter meningkatkan probabilitas kemacetan kredit, dan karenanya mendorong bank-bank enggan menyalurkan kredit. Bukti empiris ini mendukung eksistensi pengaruh asimetris kebijakan moneter yang cenderung lebih kuat dalam kondisi resesi dibandingkan dalam periode booming. 
Sementara itu, studi empiris mengenai saluran neraca perusahaan (firms balance sheet channel) pada umumnya memfokuskan pada dua pertanyaan penting dalam transmisi kebijakan moneter. Pertama, apakah kondisi neraca berperan penting dalam mempengaruhi keputusan investasi perusahaan. Kedua, bagaimana kebijakan moneter berpengaruh terhadap kondisi neraca perusahaan dan keputusan investasi mereka. Untuk kasus Indonesia, beberapa studi telah dilakukan sebelumnya dalam konteks pengujian kendala keuangan dalam keputusan investasi perusahaan. Hariss et. al. (1994) dan Goeltom (1995) menggunakan model akselerator dalam perilaku investasi dengan menggunakan data panel perusahaan manufaktur selama periode 1983-1989 untuk menyelidiki apakah liberalisasi keuangan telah mengurangi kendala keuangan dalam keputusan investasi perusahaan. Dalam konteks yang agak berbeda, dengan menggunakan data panel dari perusahaan publik untuk periode 1992-1997, Agung (2000) menyelidiki peran aliran kas dan leverage dalam keputusan investasi perusahaan untuk membuktikan bekerjanya saluran neraca perusahaan di Indonesia.

Studi lanjutan mengenai saluran neraca perusahaan dilakukan Agung et. al. (2002) dengan memasukkan pula data untuk periode setelah krisis dari 1992-1999. Bukti empiris dari studi ini menunjukkan pentingnya kondisi neraca, khususnya arus kas dan leverage, dalam mempengaruhi keputusan investasi perusahaan dan pengaruh tersebut lebih besar pada perusahaan kecil dibandingkan dengan perusahaan besar. Sensitivitas investasi terhadap kondisi neraca perusahaan ternyata meningkat selama periode kontraksi moneter dibandingkan dengan periode ekspansi moneter. Bukti-bukti empiris tersebut menunjukkan pentingnya saluran neraca perusahaan dalam transmisi kebijakan moneter di Indonesia.

\section{III.4 Intermediasi Keuangan, Kebijakan Moneter, dan Kinerja Ekonomi}

Sejak selesainya program restrukturisasi perbankan tahun 1999, kondisi perbankan menunjukkan perkembangan yang semakin membaik dengan penyaluran kredit yang meningkat cukup pesat. Hal ini tidak terlepas dari berbagai langkah kebijakan yang ditempuh Pemerintah dan Bank Indonesia untuk restrukturisasi dan peningkatan ketahanan sistem perbankan di Indonesia. Secara umum, kondisi perbankan selama periode 2000-2005 terus mengalami perbaikan, ditinjau baik dari sisi permodalan, kualitas aset, profitabilitas, likuiditas, maupun fungsi intermediasi dan penyaluran kredit untuk sektor riil. Kondisi permodalan (CAR), misalnya, yang pada tahun 1999 masih negatif telah diatasi dengan program rekapitalisasi sehingga mencapai 12,7\% pada tahun 2000 dan 19\% pada tahun 2005 (Tabel II.1). Setelah mengalami kerugian yang besar akibat kriris, profitabilitas perbankan juga telah membaik dan bahkan terus meningkat, seperti tercermin pada Net Interest Income (NII) sebesar Rp6,2 triliun dan Return on Asset (ROA) sebesar 2,8\% pada tahun 2006. 
Fungsi intermediasi perbankan juga terus mengalami peningkatan. Jumlah simpanan masyarakat dalam bentuk giro, tabungan, dan deposito selama periode 2000-2005 meningkat rata-rata 9.38\% per tahun menjadi Rp1.091,3 triliun. Bahkan peningkatan kredit lebih besar lagi, yaitu sebesar 24,71\% pada tahun 2004 dan 21,39\% pada tahun 2005 mencapai Rp.722,4 triliun. Sebagai hasilnya, fungsi intermediasi perbankan yang diukur dengan Loan to Deposit Ratio (LDR) meningkat dari hanya 45,8\% tahun 2000 menjadi 66,2\% pada tahun 2005. Demikian pula, kualitas kredit juga mengalami perbaikan, seperti tercermin pada penurunan Non-Perfoming Loans (NPLs) menjadi 5,8\% (gross) dan 1,7\% (net) pada tahun $2004 .{ }^{8}$

\begin{tabular}{l|r|r|r|r|r|r|}
\multicolumn{7}{c|}{ Tabel II.1 } \\
\multicolumn{7}{|c|}{ Indikator Kinerja Perbankan } \\
\multicolumn{1}{|c|}{ Indikator } & $\mathbf{2 0 0 0}$ & $\mathbf{2 0 0 1}$ & $\mathbf{2 0 0 2}$ & $\mathbf{2 0 0 3}$ & $\mathbf{2 0 0 4}$ & $\mathbf{2 0 0 5 *}$ \\
\hline - Total Aset (T Rp) & $1.030,5$ & $1.099,7$ & $1.112,2$ & $1.196,2$ & $1.272,3$ & $1.428,1$ \\
- DPK (T Rp) & 699,1 & 797,4 & 835,8 & 888,6 & 963,1 & $1.091,3$ \\
- Kredit (T Rp) & 320,4 & 358,6 & 410,3 & 477,2 & 595,1 & 722,4 \\
- LDR (\%) & 45,8 & 45,0 & 49,1 & 53,7 & 61,8 & 66,2 \\
- NII (T Rp) & 2,9 & 3,1 & 4,0 & 3,2 & 6,3 & 6,2 \\
- ROA (\%) & 0,9 & 1,4 & 1,9 & 2,5 & 3,5 & 2,8 \\
- NPL - Gross (\%) & 18,8 & 12,1 & 8,1 & 8,2 & 5,8 & 8,7 \\
- NPL - Net (\%) & 5,8 & 3,6 & 2,1 & 3,0 & 1,7 & 5,0 \\
- CAR (\%) & 12,7 & 20,5 & 22,5 & 19,4 & 19,4 & 19,6 \\
- Jumlah bank & 151 & 145 & 141 & 138 & 133 & 131 \\
- Jumlah kantor & 6.509 & 6.765 & 7.001 & 7.730 & 7.939 & 8.191 \\
\hline
\end{tabular}

Penyaluran kredit oleh perbankan umumnya lebih banyak untuk sektor UMKM dan khususnya dalam bentuk kredit konsumsi dan modal kerja (Tabel II.2). Selama periode 20012005 posisi kredit perbankan kepada sektor UMKM mengalami peningkatan yang rata-rata sekitar 30\% per tahun. Dengan peningkatan yang pesat ini, pangsa kredit UMKM terhadap total kredit perbankan semakin besar dan bahkan telah melampaui kredit non-UMKM. Pada tahun 2001, misalnya, nilai outstanding kredit kepada sektor UMKM mencapai Rp121,4 triliun atau baru sebesar 38,4\% dari total outstanding kredit perbankan. Akan tetapi, pada tahun 2005 posisi kredit UMKM telah mencapai Rp347,9 triliun, atau 50,7\% dari total kredit perbankan. Penyaluran kredit perbankan yang semakin didominasi untuk sektor UMKM seperti ini tidak terlepas dari kondisi sektor riil, khususnya sektor korporasi yang masih mengalami kesulitan

8 Kualitas kredit kemudian mengalami penurunan pada tahun 2005 dengan diberlakukannya ketentuan baru mengenai klasifikasi kredit perbankan, di samping meningkatnya resiko kredit dan resiko suku bunga sebagai akibat kebijakan moneter cenderung ketat yang ditempuh Bank Indonesia dalam rangka pengendalian inflasi dan nilai tukar rupiah khususnya sejak triwulan II tahun 2005. 
keuangan dan produksi akibat krisis di samping permasalahan iklim investasi dan permasalahan struktural lainnya.

\begin{tabular}{|c|c|c|c|c|c|}
\hline \multicolumn{6}{|c|}{$\begin{array}{c}\text { Tabel II.2 } \\
\text { Perkembangan Kredit UMKM }\end{array}$} \\
\hline Keterangan & 2001 & 2002 & 2003 & 2004 & $2005^{*}$ \\
\hline Posisi (Triliun Rp): & 121.4 & 161,0 & 207,1 & 271,1 & 347,9 \\
\hline 1. Kredit Modal Kerja & 54,4 & 73,7 & 91,1 & 111,6 & 138,0 \\
\hline 2. Kredit Investasi & 15,8 & 17,4 & 22,8 & 28,5 & 33,0 \\
\hline 3. Kredit Konsumsi & 51,2 & 69,9 & 93,2 & 131,0 & 176,9 \\
\hline Pertumbuhan (\%): & & $\underline{32,7}$ & 28,6 & 30,9 & 28,3 \\
\hline 1. Kredit Modal Kerja & & 35,6 & 23,7 & 22,5 & 23,6 \\
\hline 2. Kredit Investasi & & 9,7 & 31,1 & 25,0 & 16,1 \\
\hline 3. Kredit Kosumsi & & 36,7 & 33,3 & 40,6 & 35,1 \\
\hline Rasio Kredit UMKM/ & & & & & \\
\hline Kredit Perbankan (\%) & 38,4 & 39,2 & 47,1 & 48,5 & 50,7 \\
\hline
\end{tabular}

Di samping langkah-langkah kebijakan restrukturisasi perbankan, perbaikan kinerja dan fungsi intermediasi perbankan sejak tahun 2000 tersebut juga tidak dapat dilepaskan dari kebijakan moneter yang ditempuh Bank Indonesia. Dalam kaitan ini, dari sisi kebijakan moneter telah terjadi pelonggaran khususnya selama periode 2001-2004. Suku bunga SBI jangka waktu satu bulan mengalami penurunan dari 17,62\% pada akhir Desember 2001 menjadi hanya 7,31\% pada Oktober 2004. Pelonggaran kebijakan moneter ini dimungkinkan dengan menurunnya inflasi, yaitu dari 12,55\% pada tahun 2001 menjadi 5,06\% pada tahun 2003, dan relatif stabilnya nilai tukar rupiah. Penurunan suku bunga SBI tersebut telah diikuti oleh penurunan suku bunga deposito yaitu dari 16,07\% pada akhir Desember 2001 menjadi hanya 6,62\% pada akhir Desember 2003. Namun demikian, suku bunga kredit masih relatif tinggi, yaitu untuk kredit modal kerja, kredit investasi, dan kredit konsumsi masing-masing sebesar 15,07\%, 15,68\%, dan 18,69\% pada akhir tahun 2003. Perkembangan ini mengkonfirmasi studi transmisi moneter melalui saluran suku bunga di atas yang menunjukkan adanya tenggat waktu perubahan suku bunga perbankan terhadap suku bunga kebijakan moneter (Kusmiarso et.al., 2002). Hal ini tidak saja karena mekanisme manajemen aset dan kewajiban pada bankbank tetapi juga masih relatif tingginya ekspektasi mengenai resiko kredit macet.

Dengan perbaikan kinerja perbankan dan peningkatan penyaluran kredit tersebut telah berangsur-angsur mampu memenuhi kebutuhan pembiayaan bagi kegiatan investasi dalam 
perekonomian. Hal ini terlihat dari membaiknya sumber-sumber pendorong pertumbuhan ekonomi Indonesia dari bertumpu pada konsumsi hingga tahun 2003 kemudian bergeser ke investasi pada tahun 2004. Pada tahun 2003, misalnya, investasi hanya tumbuh sebesar 1,4\% yang berarti jauh lebih rendah dari rata-rata pertumbuhan investasi periode sebelum krisis, yaitu sebesar 11,7\% pada tahun 1989-1997. Peningkatan pertumbuhan investasi yang lebih besar terjadi pada tahun 2004 yang mencapai 15,1\% dan diperkirakan sebesar 10,5\% pada tahun 2005. Hal ini tidak terlepas dari peningkatan kredit perbankan yang demikian pesat, yaitu mencapai 24,71\% tahun 2004 dan 21,39\% tahun 2005 tersebut, sejalan dengan kebijakan moneter akomodatif yang ditempuh bank sentral dan optimisme perbaikan di sektor riil yang terjadi dalam periode ini. ${ }^{9}$

Perkembangan tersebut menunjukkan bahwa, dengan dominannya peran perbankan dalam perekonomian Indonesia, intermediasi keuangan menjadi salah satu faktor yang menentukan efektivitas kebijakan moneter dan kinerja perekonomian secara keseluruhan. Pada periode 1997-1999, krisis nilai tukar dan krisis perbankan telah menyebabkan buruknya kondisi perbankan dan ketidakefektifan kebijakan moneter sehingga menyulitkan proses pemulihan ekonomi. Namun demikian, dengan berbagai langkah yang telah ditempuh Pemerintah dan Bank Indonesia, kinerja perbankan terus mengalami perbaikan pada periode 2000-2005 sehingga mendukung kebijakan moneter dan peningkatan kinerja perekonomian secara keseluruhan.

\section{PENTINGNYA KOORDINASI KEBIJAKAN MONETER DAN PERBANKAN}

Keterkaitan yang erat antara kesehatan dan kestabilan perbankan dengan kebijakan moneter seperti di atas menunjukkan pentingnya koordinasi antara kebijakan moneter (perspektif makro) dan kebijakan perbankan (perspektif mikro). Seperti diuraikan di atas, perbankan yang aman, sehat, dan stabil merupakan sasaran kebijakan perbankan yang pada dasarnya dilakukan melalui instrumen-instrumen perizinan, pengaturan kehati-hatian, pengawasan langsung maupun tidak langsung, serta penanganan bank-bank yang mengalami kesulitan. Sementara dalam konteks kebijakan moneter, sasaran akhir yang diutamakan adalah kestabilan harga (inflasi), dan atau kestabilan nilai tukar (kurs) pada sejumlah negara, yang akan dicapai melalui operasi moneter yang pada umumnya melalui pengendalian suku bunga di pasar uang. Dengan peran perbankan dalam proses penciptaan uang dan transmisi kebijakan moneter seperti diuraikan di atas, pelaksanaan kebijakan moneter jelas tidak dapat berjalan efektif tanpa adanya

\footnotetext{
9 Peningkatan investasi kemudian terkendala dengan melambungnya harga minyak dunia dan penguatan dolar AS yang menimbulkan tekanan terhadap inflasi dan nilai tukar sejak pertengahan tahun 2005, khususnya dengan kenaikan harga BBM yang harus ditempuh pemerintah.
} 
kondisi perbankan yang sehat dan stabil. Demikian pula, perubahan suku bunga, nilai tukar, dan inflasi akibat pelaksanaan kebijakan moneter jelas akan berpengaruh pada kesehatan dan kestabilan perbankan melalui perubahan resiko pasar yang terkandung pada kondisi keuangan dan permodalan perbankan.

Dasar pemikiran seperti ini berpengaruh besar pada proses perumusan maupun pelaksanaan kebijakan moneter di sejumlah bank sentral. Apapun rezim kebijakan moneter yang dianut, semakin penting bagi bank sentral untuk memantau dan menganalisis kondisi perbankan baik secara individual secara sistem di dalam proses internal di bank sentral. Pemantauan dan analisis dimaksud tidak saja diarahkan untuk menentukan perkembangan kondisi kesehatan maupun kestabilan sistem perbankan, tetapi juga untuk menentukan seberapa jauh kondisi perbankan akan berpengaruh pada efektivitas pelaksanaan kebijakan moneter dan bagaimana pelaksanaan kebijakan moneter berpengaruh pada kondisi perbankan.

Dalam tataran teoritis, mempertimbangkan pentingnya peran dan institusi perbankan, Joseph E. Stiglitz mengajukan paradigma baru dalam teori moneter yang didasarkan kepada penawaran dan permintaan kredit (Stiglitz and Greenwald, 2003). Bank amat berperan dalam menentukan penawaran kredit karena adanya risiko yang harus dihadapi ketika mereka memberikan kredit (default risks) sebagai akibat adanya pemahaman pelaku pasar yang tidak sama terhadap informasi yang tersedia (asymmetric information). Dengan demikian, pemahaman atas perilaku dan kemampuan bank dalam mengelola risiko amat penting ketika dihadapkan pada adanya ketidaksempurnaan pasar (imperfect information). Mengingat perubahan di sektor perbankan amat berperan dalam menjelaskan perubahan perilaku besar-besaran moneter, maka perilaku bank tersebut akan menentukan perilaku perekonomian secara keseluruhan (institutional economics). Ini berbeda dengan teori moneter tradisional yang menganggap perkembangan institusi perbankan sesuatu yang given atau eksogen.

Berdasarkan pemikiran seperti ini, beberapa implikasi kebijakan diajukan dari paradigma baru kebijakan moneter tersebut. Pertama, stance kebijakan moneter (ketat/longgar) lebih tepat apabila diukur dengan mendasarkan pada ketersediaan kredit dalam ekonomi daripada suku bunga riil. Kedua, semakin perlunya bagi bank sentral memahami bagaimana dampak kebijakan moneter terhadap perilaku perbankan dan demikian pula sebaliknya. Ketiga, kebijakan pengaturan perbankan, sebagaimana kebijakan moneter, perlu didasarkan pada teori perilaku perbankan, dan karenanya diperlukan sinkroninasi yang baik di antara kedua kebijakan tersebut.

Dalam tataran implementatif, pentingnya pertimbangan kondisi perbankan dalam perumusan kebijakan moneter, atau sebaliknya, berpengaruh pada beberapa aspek baik yang menyangkut pengorganisasian di bank sentral maupun cakupan variabel informasi yang 
dipergunakan dalam perumusan kebijakan. Dalam aspek organisasi, misalnya, sejumlah bank sentral melakukan penguatan organisasi dengan membentuk dua kelompok dalam organisasinya, yaitu kelompok kebijakan moneter (monetary stability wing) dan kelompok kestabilan sistem keuangan (financial system stability wing). Masing-masing kelompok kebijakan tersebut biasanya dipimpin oleh pimpinan tertinggi (deputy governor) yang secara periodik merumuskan dan menetapkan kebijakan moneter dan perbankan dalam suatu rapat dewan gubernur di bank sentral yang bersangkutan. Dengan pengaturan demikian, sinkroninasi dan koordinasi antara kebijakan moneter dan kebijakan perbankan secara formal diatur dalam organisasi, mekanisme kerja, dan proses pengambilan keputusan di internal bank sentral.

Di samping penyempurnaan pengorganisasian, penguatan dalam aspek cakupan dan kedalaman variabel informasi yang dipergunakan sebagai dasar perumusan kebijakan juga dilakukan. Dalam perumusan kebijakan moneter, analisis mengenai kondisi perbankan perlu dilakukan tidak saja untuk menganalisis perkembangan uang beredar, suku bunga, dan kredit, tetapi juga kondisi mikro perbankan dan perusahaan dalam rangka untuk menilai seberapa efektif dan kuat transmisi kebijakan moneter dapat berlangsung. Analisis seperti ini semakin penting dalam konteks penerapan rezim kebijakan moneter yang forward looking seperti halnya dalam inflation targeting framework. Dengan semakin mendalami dan meyakini kekuatan dan tenggat waktu saluran-saluran penting dalam transmisi moneter, bank sentral semakin dapat mengantisipasi dan mengarahkan stance dan sinyal moneter yang diputuskan saat ini kepada arah pergerakan ekonomi dan sasaran inflasi yang ingin dicapai ke depan.

Demikian pula, dalam perumusan dan pelaksanaan tugas pengaturan dan pengawasan bank, bank sentral juga semakin dituntut untuk menganalisis dan menilai seberapa jauh dan besar pengaruh kebijakan moneter terhadap resiko yang dihadapi oleh perbankan. Dalam kaitan ini, perubahan kebijakan moneter khususnya yang tercermin pada volatilitas inflasi, suku bunga, dan nilai tukar perlu dianalisis dan dinilai seberapa besar dampaknya terhadap perubahan nilai pada pos-pos neraca dan rugi-laba bank-bank. Fenomena ini sejalan dengan semakin ditekankannya manajemen atau pengawasan berbasis resiko oleh bank sentral pada perbankan. Dengan demikian, fokus pengawasan perbankan tidak saja terbatas pada penilaian tingkat kesehatan yang umumnya dikenal dengan CAMEL, tetapi juga pada penilaian berbagai resiko yang dihadapi oleh perbankan. Hal ini sejalan dengan prinsip-prinsip pengawasan bank yang efektif seperti dikenal dengan 25 Basle Core Principles.

Pentingnya bagi bank sentral untuk melakukan analisis dan penilaian mengenai kesehatan dan stabilitas perbankan, atau stabilitas sistem keuangan secara keseluruhan, dapat dirujuk dari setidaknya dua aspek. Pertama, hal ini merupakan konsekuensi logis dari eratnya kaitan antara aspek ini dengan perumusan dan pelaksanaan kebijakan moneter seperti diuraikan di 
atas. Bank sentral tidak mungkin dan tidak akan dapat secara efektif menempuh kebijakan moneter dalam mempengaruhi kegiatan ekonomi dan keuangan untuk mencapai sasaran inflasi (dan atau stabilitas nilai tukar) tanpa tidak mengetahui dan menganalisis kondisi dan stabilitas sistem keuangan. Kedua, penilaian stabilitas sistem keuangan tersebut juga harus dilakukan oleh bank sentral karena pada akhirnya bank sentral akan terlibat juga dalam penyediaan pembiayaan dalam hal terjadi kesulitan yang menimpa perbankan atau sistem keuangan secara keseluruhan. Penyediaan pembiayaan ini terkait dengan fungsi bank sentral sebagai lenders of last resort (LOLR) ataupun dalam pemberian dana talangan dalam kerangak financial safety net (FSN) yang selanjutnya akan menjadi beban anggaran Pemerintah. Aspek yang terakhir inilah yang mendorong perlunya suatu mekanisme koordinasi, dalam hal terjadi pemisahan pengawasan bank dari bank sentral, dalam stabilitas sistem keuangan tersebut antara Pemerintah, bank sentral, dan otoritas pengawasan sektor keuangan (FSA).

\section{PENUTUP}

Paper ini menguraikan eratnya keterkaitan antara kondisi kesehatan dan stabilitas perbankan pada khususnya dan sistem keuangan pada umumnya dengan kebijakan moneter. Stabilitas perbankan dan stabilitas moneter dapat dikatakan merupakan dua sisi yang saling berpengaruh dan menentukan satu sama lain. Kebijakan moneter tidak efektif tidak akan efektif apabila perbankan tidak sehat dan stabil karena proses perputaran uang dan mekanisme transmisi kebijakan moneter sebagian besar berlangsung melalui perbankan. Demikian sebaliknya perubahan kebijakan moneter berdampak besar pada kondisi kesehatan dan stabilitas perbankan karena perubahan suku bunga, nilai tukar, dan inflasi merupakan tiga elemen penting yang menentukan resiko pasar yang dihadapi perbankan. Keterkaitan ini bersumber dari peran penting perbankan baik dari perspektif mikro maupun makro, yaitu dalam proses penciptaan uang dan mekanisme sistem pembayaran dalam ekonomi, fungsi intermediasi dalam memobilisasi dana masyarakat dan menyalurkan kredit dan pembiayaan kepada dunia usaha, serta dalam pengembangan produk dan pasar keuangan.

Eratnya keterkaitan antara perbankan dan moneter tersebut nampak jelas pada perkembangan di Indonesia khususnya sejak krisis 1997. Perkembangan tersebut menunjukkan bahwa, dengan dominannya peran perbankan dalam perekonomian Indonesia, intermediasi keuangan menjadi salah satu faktor yang menentukan efektivitas kebijakan moneter dan kinerja perekonomian. Pada periode 1997-1999, krisis nilai tukar dan krisis perbankan telah menyebabkan buruknya kondisi perbankan dan ketidakefektifan kebijakan moneter sehingga menyulitkan proses pemulihan ekonomi. Namun demikian, dengan berbagai langkah yang 
telah ditempuh Pemerintah dan Bank Indonesia, kinerja perbankan terus mengalami perbaikan pada periode 2000-2005 sehingga mendukung kebijakan moneter dan peningkatan kinerja perekonomian secara keseluruhan.

Uraian di atas menunjukkan pentingnya koordinasi kebijakan moneter dan kebijakan perbankan khususnya dan kebijakan di sektor keuangan pada umumnya. Ke depan, diperlukan berbagai langkah untuk semakin mendorong perbaikan pada kondisi lembaga-lembaga keuangan serta pengembangan produk dan pasar keuangan untuk mengatasi permasalahan disintermediasi keuangan tersebut. Koordinasi kebijakan yang diperlukan tidak saja terbatas pada perlunya analisis yang lebih mendalam dan menyeluruh keterkaitan antara kondisi kesehatan dan stabilitas perbankan dan sistem keuangan dengan langkah-langkah kebijakan moneter, tetapi juga antara kebijakan di sektor keuangan dengan kebijakan di sektor riil. 


\section{DAFTAR PUSTAKA}

Agung, Juda (1998). "Financial deregulation and bank lending channel of monetary policy in developing countries: The case of Indonesia", Asian Economic Journal, Vol. 12, No.3, 273294.

Agung, Juda (2000). "Financial constraints, firm's investment and channel of monetary policy for Indonesia", Buletin Ekonomi Moneter dan Perbankan, Vol. 3, No. 1, pp. 146-178.

Agung, Juda, Bambang Kusmiarso, Bambang Pramono, Erwin G. Hutapea, Andry Prasmuko, and Nugroho Joko Prastowo (2001a), Credit Crunch in Indonesia in the Aftermath of the Crisis, Bank Indonesia: Directorate of Economic Research and Monetary Policy, Jakarta, March 2001.

Agung, Juda, Rita Morena, Bambang Pramono, and Nugroho Joko Prastowo (2001b) "Bank Lending Channel of Monetary Transmission in Indonesia", dalam Perry Warjiyo dan Juda Agung, eds.. Transmission Mechanism of Monetary Policy in Indonesia. Bank Indonesia: Jakarta, Juli 2002.

Agung, Juda, Rita Morena, Bambang Pramono, and Nugroho Joko Prastowo (2001c) "Monetary Policy and Firm Investment: Evidence for Balance Sheet Channel in Indonesia", dalam Perry Warjiyo dan Juda Agung, eds., Transmission Mechanism of Monetary Policy in Indonesia. Bank Indonesia: Jakarta, Juli 2002.

Enoch, Charles, Barbara Baldwin, Oliver Frecaut, dan Arto Kovanen (2001), "Indonesia: Anatomy of a Banking Crisis -Two Years of Living Dangerously, 1997-1999", IMF Working Paper WP/ 01/52, May.

George, E.A.J (1997), "Are Banks Still Special?" dalam Charles Enoch dan John H. Green, eds., Banking Soundness and Monetary Policy. Washington, DC: IMF.

Goeltom, M.S. (1995). Indonesia's Financial Liberalization: An Empirical Analysis of 1981-1988 Panel Data. Institute of Southeast Asian Studies. Singapore.

Guitan, Manuel (1997), "Banking Soundness: The Other Dimension of Monetary Policy" dalam Charles Enoch dan John H. Green, eds., Banking Soundness and Monetary Policy. Washington, DC: IMF.

Harris, J.R., Schiantarelli, F., and Siregar, M.G. (1994). "The effect of financial liberalisation on the capital structure and investment decisions of Indonesian manufacturing establishments", The World Bank Economic Review, 8, pp.17-47. 
Kusmiarso, Bambang, Elizabeth Sukowati, Andry Prasmuko, Sudiro Pambudi, Dadal Angkoro, Iss Savitri Hafid (2002). "Interest Rate Channel of Monetary Transmission in Indonesia" dalam Perry Warjiyo dan Juda Agung, eds, Transmission Mechanism of Monetary Policy in Indonesia. Bank Indonesia: Jakarta, Juli 2002.

Sinclair, Peter (2001), "Financial Stability and Central Banks: An Introduction" dalam Richard A. Brealey et al, eds. Financial Stability and Central Banks: A Global Perspective. London: Routledge, 2001.

Stigliz, Joseph E. dan Bruce Greenwald (2003), Towards a New Paradigm in Monetary Economics, Cambridge University Press, 2003.

Suseno dan Piter Abdullah (2003), Sistem dan Kebijakan Perbankan Indonesia, Seri Kebanksentralan No. 7, Bank Indonesia: Pusat Pendidikan dan Studi Kebanksentralan (PPSK).

Warjiyo, Perry (2002). "Towards Inflation Targeting: The Case of Indonesia" in Inflation Targeting: Theories, Empirical Models and Implementation in Pacific Basin Countries. Bank of Korea: Seoul, January 2002.

Warjiyo, Perry (2004), Mekanisme Transmisi Kebijakan Moneter di Indonesia. Seri Kebanksentralan No. 11, Bank Indonesia: Pusat Pendidikan dan Studi Kebanksentralan (PPSK).

Warjiyo, Perry and Doddy Zulverdi (1998). "Penggunaan Suku Bunga Sebagai Target Operasional Kebijakan Moneter di Indonesia", Buletin Ekonomi Monter dan Perbankan, Vol. 1, no.1.

Warjiyo, Perry dan Juda Agung (2002). Transmission Mechanism of Monetary Policy in Indonesia. Bank Indonesia: Jakarta, Juli 2002.

Warjiyo, Perry dan Solikin (2003). Kebijakan Moneter di Indonesia. Seri Kebanksentralan No. 6, Bank Indonesia: Pusat Pendidikan dan Studi Kebanksentralan (PPSK). 